\title{
BEEKEEPING IN PAKISTAN (HISTORY, POTENTIAL, AND CURRENT STATUS)
}

By:

\section{Dr. Khalid Ali Khan*}

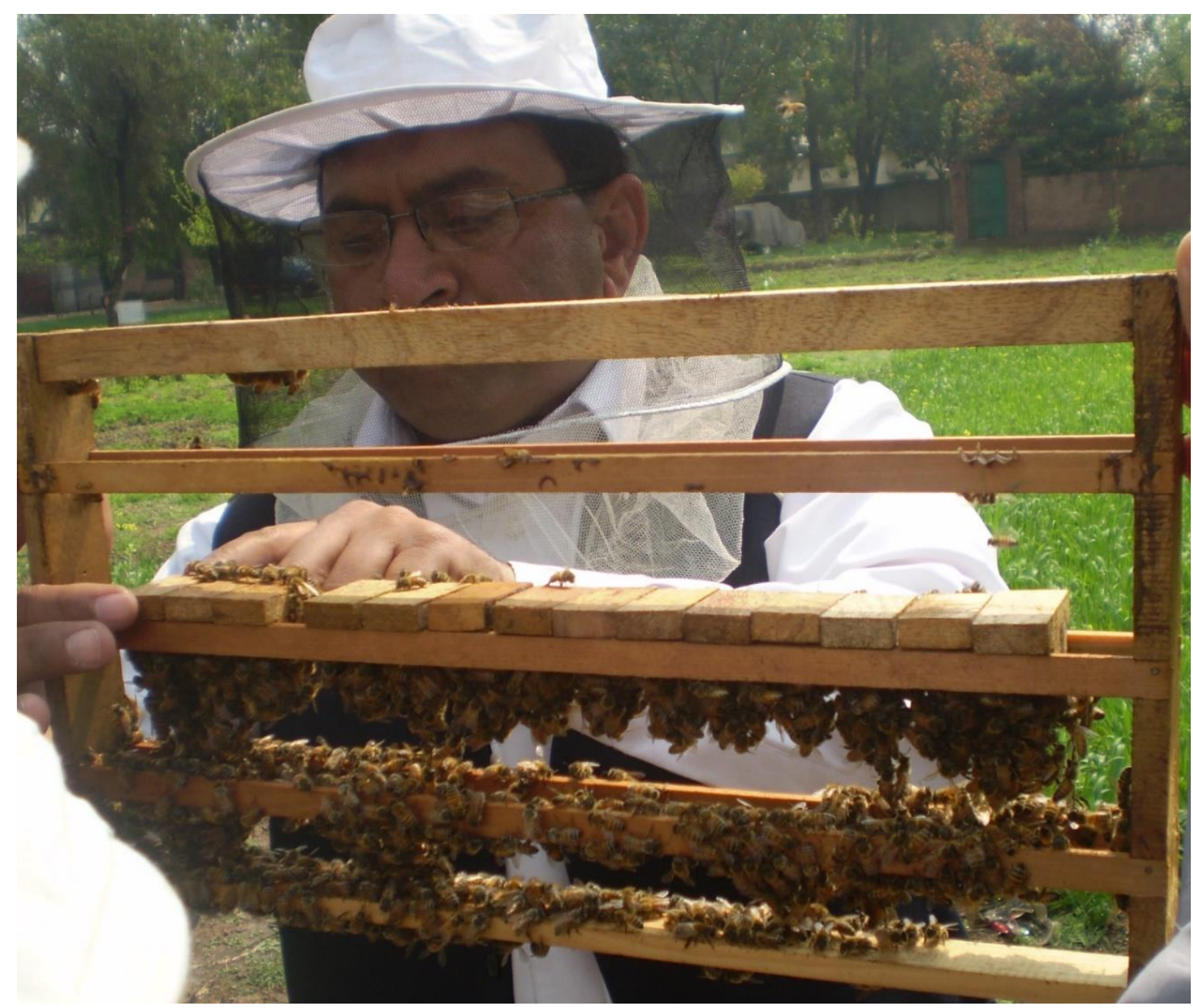

* Assistant Professor of Apiculture/Entomology at

Unit of Bee Research and Honey Production, Faculty of Science, King Khalid University, P.O. Box 9004, Abha 61413, Saudi Arabia Email address: khalidtalpur@hotmail.com; Mobile No. +923445111913; +966583028247 


\begin{abstract}
Pakistan is an important country located in South Asia and ranks the world's sixth most populous country. It has diverse landscapes with their own specific vegetation. The country specific vegetative diversity has a great ecological and economic impact on the conservation of local fauna. It has huge potential for sustainable beekeeping industry if properly exploited. Beekeeping in Pakistan is mainly focused in Khyber Pakhtunkhwa and central and north regions of Punjab provinces but nowadays it is growing rapidly across the country. Honey produced in Pakistan enjoys good repute in the Middle East due to its unique taste and quality. Pakistan exports around 4000 tons of the honey with the worth of about \$23.00 million to Arab countries every year.
\end{abstract}

Keywords: Beekeeping; honey bees; honey production; bee forage plants; honey producing capacity.

\title{
Introduction
}

Pakistan is an important country located in South Asia and ranks the world's sixth most populous country. It is situated transversely between $24^{\circ}$ and $37^{\circ}$ north latitudes and $61^{\circ}$ and $75^{\circ}$ east longitudes, spreading over an area of 87.98 million ha. It occupies a coastline of about 1,046 kilometers stretching along the Arabian Sea and the Gulf of Oman. Pakistan has international borders with Afghanistan, India, China, and Iran to the west, east, in the far northeast, and to the southwest respectively. In the northwest, Afghanistan's Wakhan Corridor separates Pakistan narrowly from Tajikistan. It also has a maritime border with Oman. Pakistan has a diverse landscape characterized by the high mountain ranges, picturesque valleys, the desolate plateaus, the Indus basin, the sandy deserts, the beautiful sandy beaches, the blue pools, and the mangrove forests along the Arabian sea, each landscape characterized by its own specific vegetation. 


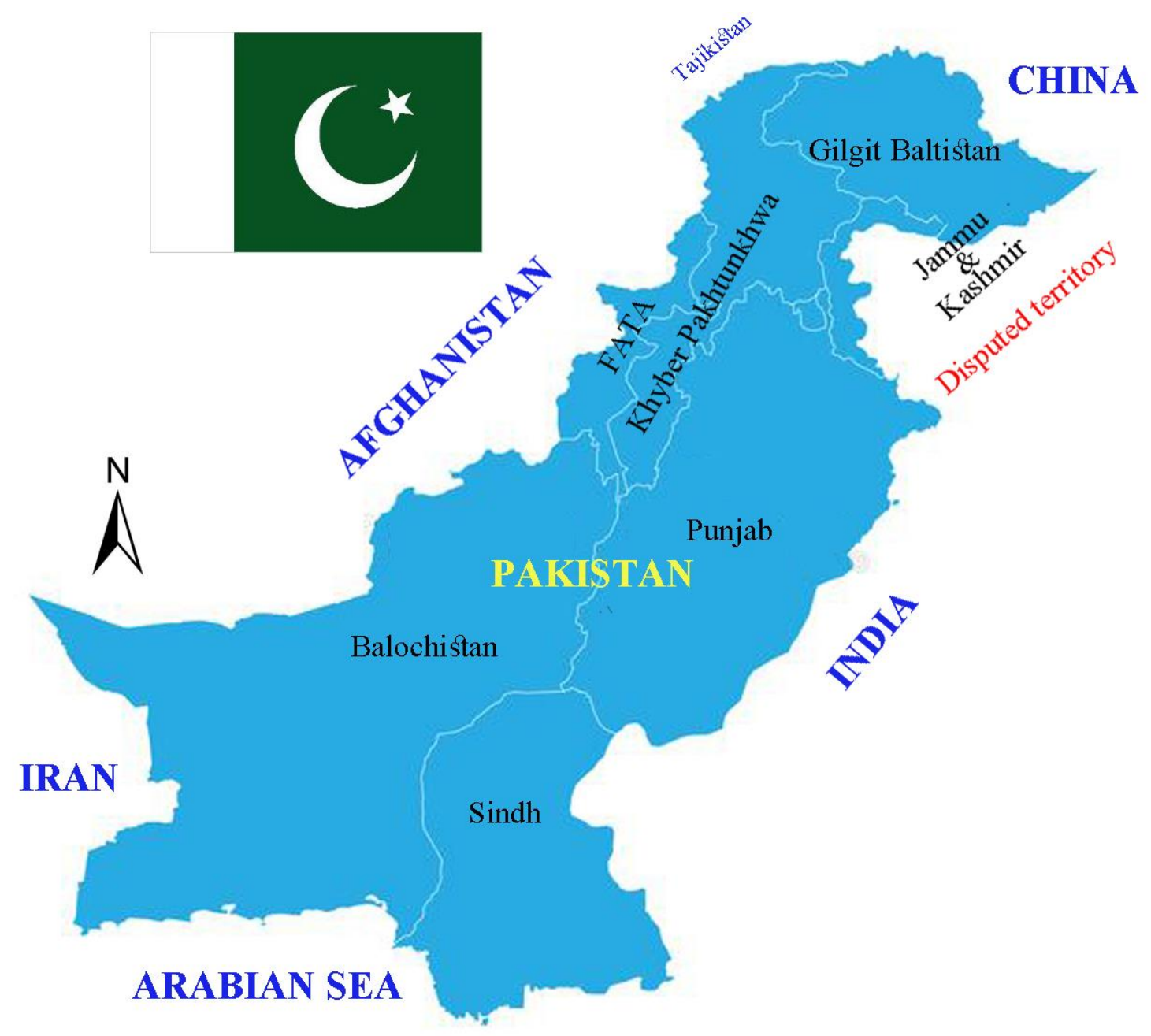

Figure 1. Map of Pakistan along with all provinces. 


\section{Topography and landscape of Pakistan}

Pakistan has glamorous mountains in the northern areas and with western borders. Three highest mountain ranges i.e. the Himalayas, the Karakorum, and the Hindukush meet together in the north and attract many mountaineer adventurers around the globe. K-2 $(8611 \mathrm{~m})$ is the second highest peak (next to Mount Everest) and belongs to the Karakorum range that has some of the highest peaks in the world. Nanga Parbat $(8126 \mathrm{~m})$ ranks the second highest mountain in the Himalayas. This mountainous area occupies largest concentration $(>121)$ of peaks in the world and also blessed with few longest glaciers outside the Arctic region. Some smaller mountain ranges (the Suleiman range, the Salt range, the Koh Safaid range, the Toba Kakar range, the Kirthar range, and the Makran coast range) lies along the west. In addition to the mountains, the country has two important and beautiful plateaus, the Balochistan plateau and the Potwar plateau. It also has some intermountain pictorial valleys like Swat, Chitral, Peshawar, and Bannu valleys.

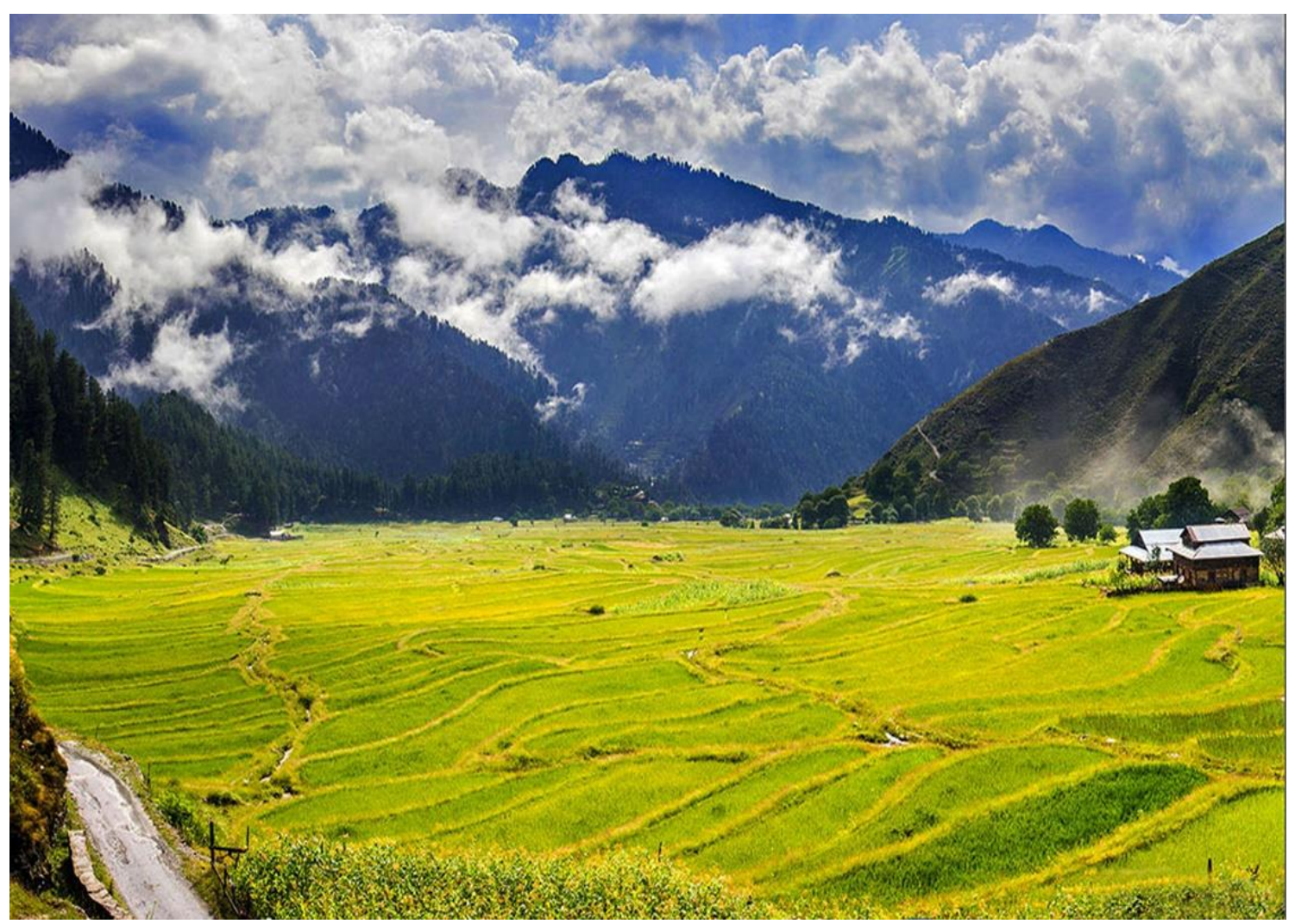

Figure 2. Leepa Valley Muzaffarabad, Azad Kashmir (Image courtesy of https://madeforpakistan.com/famous-valleys-of-pakistan/) 


\section{Climatic conditions of Pakistan}

The climate of the country is as diverse as its landscape. Annual precipitation varies from $50 \mathrm{~mm}$ in western areas of the Balochistan province uplands to almost $1,500 \mathrm{~mm}$ in the Himalayan areas. Many parts of the Balochistan, a large area of the Punjab province (south of Sahiwal city), and the Sindh province receive an annual rainfall of less than 200. The annual rainfall progressively rises from the north of Sahiwal and the true humid conditions prevail over the plain areas when annual precipitation of 1,000 $\mathrm{mm}$ and on the highlands when annual rainfall accedes from $700 \mathrm{~mm}$. The Monsoon and the Western Depression are the two important sources of rainfall in Pakistan. The monsoon rainfalls enter from the east and usually start from July to September each year. As the monsoon (Kharif season) enters from the east, therefore eastern parts of the country receive maximum rainfall.

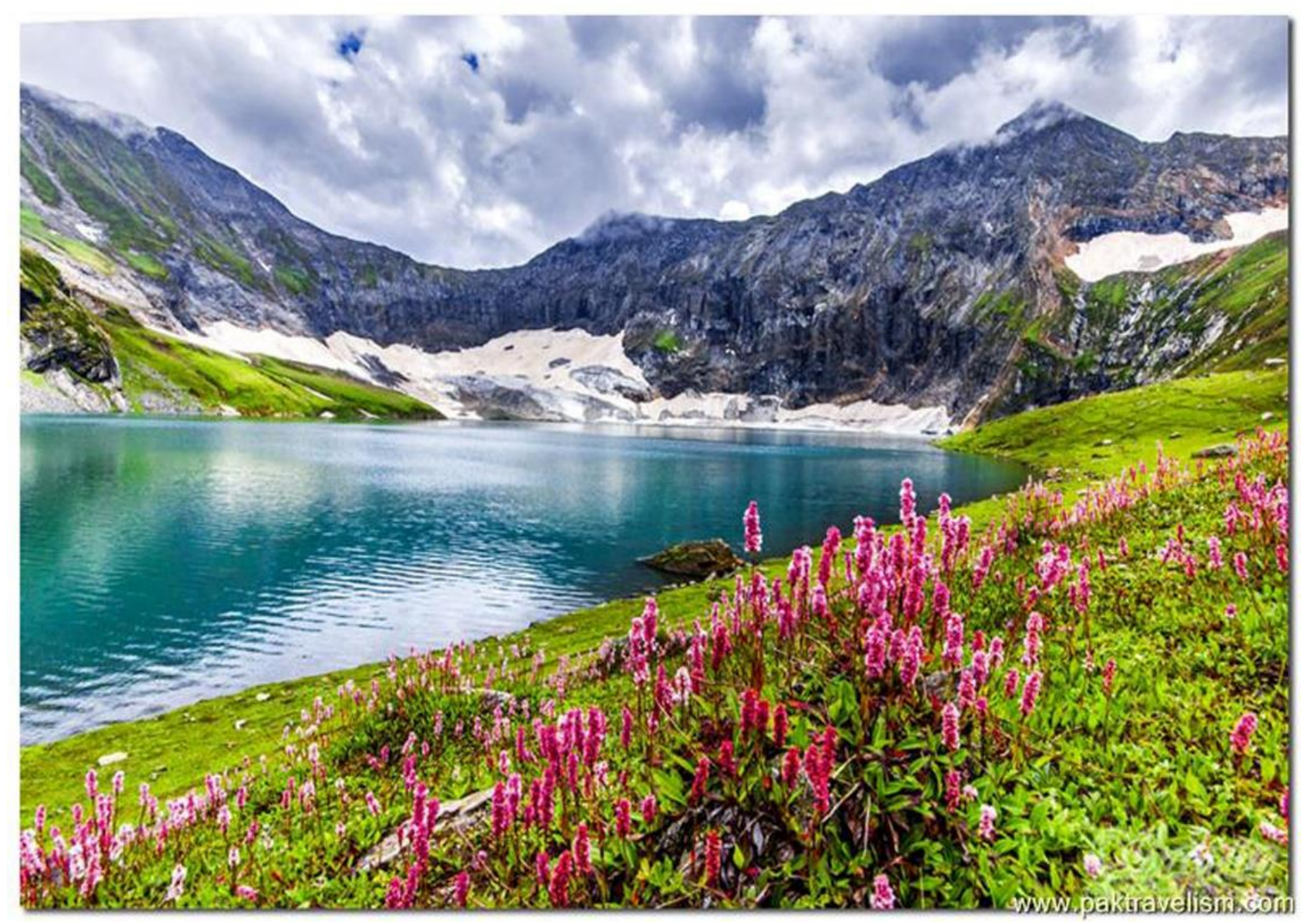

Figure 3. Ratti Gali Lake, Neelum Valley

(Image courtesy of https://www.shughal.com/the-10-most-stunning-lakes-of-pakistan/) 
After transient over Iran and Afghanistan and losing most of the moisture on the way, the western depression arrives in Pakistan from the west and bring a little amount of rainfall to the western parts of the country during December to March (Rabi season). The topography of Pakistan has diverse climates, most of the areas receive adequate rainfall in Kharif and Rabi seasons which boost the vegetative growth and enhance the flowering of numerous plant species which are rich sources of nectar and pollen for bees.

\section{Some land uses of Pakistan}

Land uses for forest cover (scrub, riverain, mangroves, and plantation), agricultural land (irrigated, rainfed, and rodkohi), rangelands, deserts, and snow/glacier are shown in table 1 which are about $5 \%, 20 \%, 27 \%, 10 \%$, and $2 \%$ respectively of total area of the country. Most of the beekeeping practices in Pakistan are focused in KPK and central and north regions of Punjab but nowadays it is growing rapidly. Beekeeping in Pakistan is not exploiting the full potential of bee forage plants found in forest cover, agriculture land including linear plantations, and rangelands. The bee flora present in the country can support up to 3.5 million bee colonies (Khan et al. 2014).

Table 1. Pakistan: Some important land uses (000, hectares )

\begin{tabular}{|c|c|c|c|c|c|c|c|}
\hline \multirow[b]{2}{*}{ S. No. } & \multirow[b]{2}{*}{ Land use } & \multicolumn{4}{|c|}{ Provinces } & \multirow[b]{2}{*}{ Pakistan } & \multirow[b]{2}{*}{$\%$} \\
\hline & & Punjab & Sindh & Balochistan & $\begin{array}{c}\text { Khyber } \\
\text { Pakhtunkhwa }\end{array}$ & & \\
\hline 1 & Forest & 855.1 & 848.3 & 508.1 & $2,311.9$ & $4,523.4$ & 5.4 \\
\hline 2 & Rangeland & $5,385.7$ & $3,961.1$ & $9,255.8$ & $3,848.7$ & $2,2451.3$ & 26.9 \\
\hline 3 & $\begin{array}{c}\text { Agricultural } \\
\text { land }\end{array}$ & $10,143.4$ & $4,465.0$ & 822.2 & $1,174.7$ & $1,6604.7$ & 19.9 \\
\hline 4 & Deserts & $1,796.9$ & $3,140.8$ & $3,189.4$ & - & $8,127.1$ & 9.7 \\
\hline 5 & Snow/Glaciers & - & - & - & $1,829.6$ & $1,829.6$ & 2.2 \\
\hline
\end{tabular}

Source: Land use atlas of Pakistan (2009), Ministry of Environment, Government of Pakistan

\section{Forest types in Pakistan}

There are many kinds of forests in Pakistan with their own specific vegetative diversity which have a great ecological and economic impact. They are helpful for the conservation of 
local fauna and may have huge potential for sustainable beekeeping industry if properly exploited. Coniferous sub-alpine forests: are found in Azad Kashmir, Dir, Swat, Chitral, Northern areas, and Hazara at an elevation of 3,350 to 3,800 m. Common vegetation includes Abies pindrow, Pinus wallichiana, Betula, Pyrus, Salix, Primula, Ranunculaceae, Aconitum heterophyllum, A. chasmanthum, A. laeve, Saussurea lappa, Rehum emodi and Podophyllum hexandrum. Coniferous dry temperate forests: are distributed (at an elevations of 1,525 to 3,350 m) across the inner arid mountain ranges, outside the operative range of the monsoon, in the northern areas, Chitral, Nilam and Kaghan valleys, and Takht-i- Suleman, Shinghar and Ziarat in Balochistan. Cedrus deodara, P. gerardiana, Juniperus excelsa, P. wallichiana, Picea smithiana, and Quercus ilex, Fraxinus, Acer, Daphne, Lonicera, Prunus, Artemisia, Astragalus Ehedra, Ephedra nebrodensis, Artemisia maritima, Carurn bulbocastanumi, Thymus, Ferula, Juglans regia, P. gerardiana, Zizyphus sativa are characteristics plant species in these forests. Coniferous Himalayan moist temperate forests are located (at an elevation of 1,373 3,050 m) in Murree, Galies, Kaghan, and Azad Kashmir. P. wallichiana, C. deodara, Picea smithiana, Abies pindrow, Quercus incana, Q. dilatata, Q. semecarpfolia, Rhododendron arboreum, Acer, Aesculus, Prunus, Ulmus, Fraxinus, Corylus, Alnus, Litsaea, Machilus, Euonymus, Ilex, Indigoferja, Lonicera, Rosa, Desmodium, Rubus, Viburnum, Strobilanthus spp., Zizyphus vulgaris, Punica ranatun, Berberis lycium, Skimmia laureola, Viola setpens, Dioscorea spp., Valeriana wallichii, Atropa acuminata, Colchicum luteum, Asparagus racenosus, and Mentha piperita are common plant species found in these forests. Coniferous sub-tropical pine forests are located in Klazara, Murree hills and Azad Kashmir. P. roxburghii, Q. incana, Lyonia ovalifolia, R. arboreum, Pistacia intecerima, Syzygium cumini, Mallotus philippinensis, Xvlosma longifolium, Q. glauca, Ficus spp. are feature plants. Scrub dry sub-tropical broad-leaved forests are classified as arid forests and propagate in the foot-hills and the lower parts of the Himalayas, the Salt range, the Kala-chitta range, and the Suleman range. The main tree species are Olea ferruginea, Acacia niodesta, Tecoma undulata, Pistacia integrima, Dodonaea viscosa, Retonia buxifolia, Capparis aphylla, Qymnospia royleana and Zizyphus spp. Scrub dry tropical thorn forests are called the "Rakh" forests located at the upper Indus plain and the desert forests in the lower Indus plain. Common plants species are A. modesta, A. niotica, Salvadora oleoides, Prosopis cineraria, Tamarix aphyla, Zizyphus spp., Cappris decidua, Tecomella undulata, Calotropis procera, A. senegal, Comliphora mukul, Egphogribia spp. Ephorbia and A. 
jacquemontii, Calllgonum spp., Suaeda, Salsola, Haloxylon, Salvadora persica., Tamarix dioica., Aristida, Eleusine, Panicum, Cenchrus, Lasiurus.

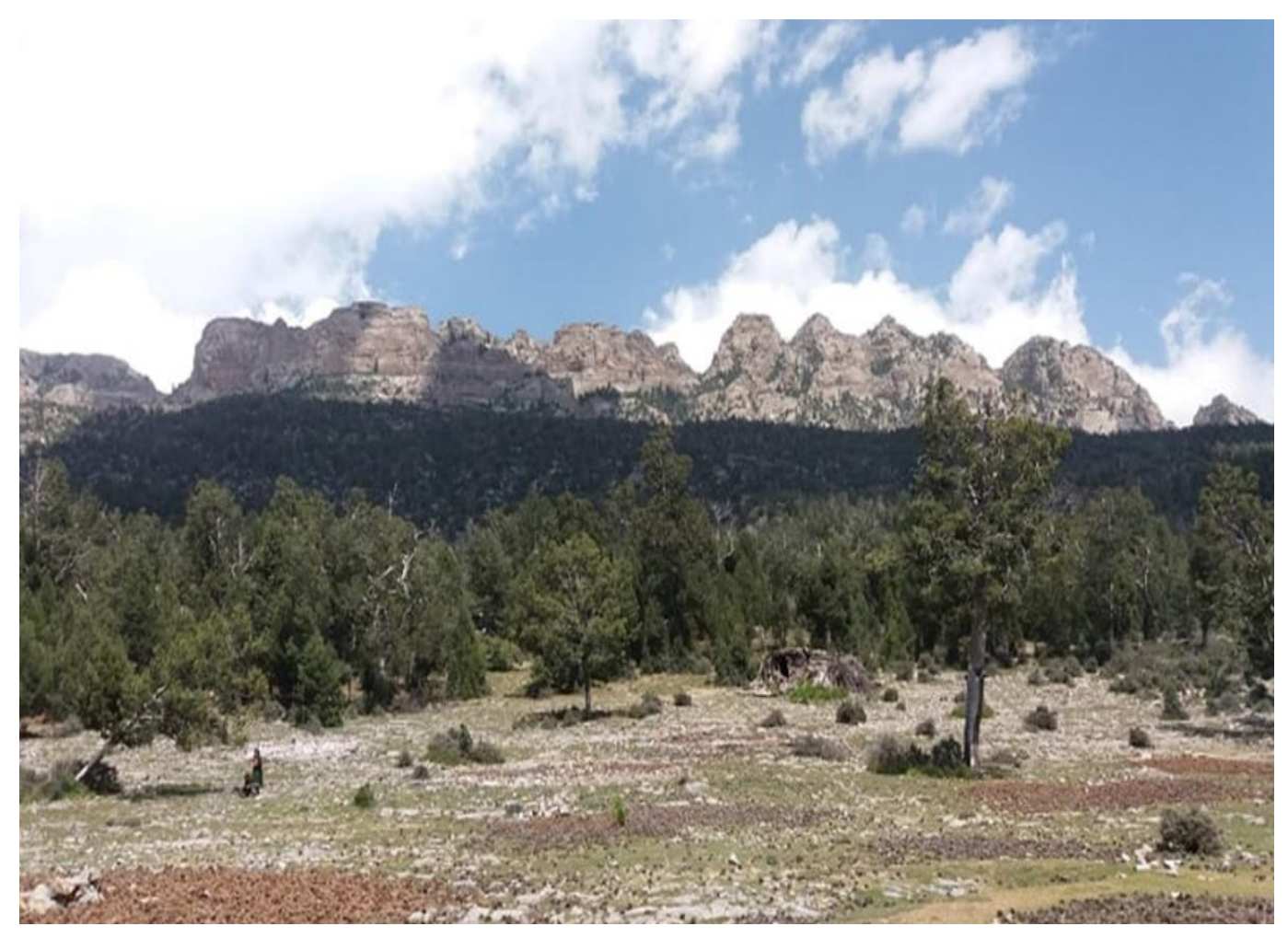

Figure 4: Koh-i-Sulaiman, Pakistan (Image courtesy of Asad Khan Betini via https://www.dawn.com/news/1399934/travel-jinn-mountain) 


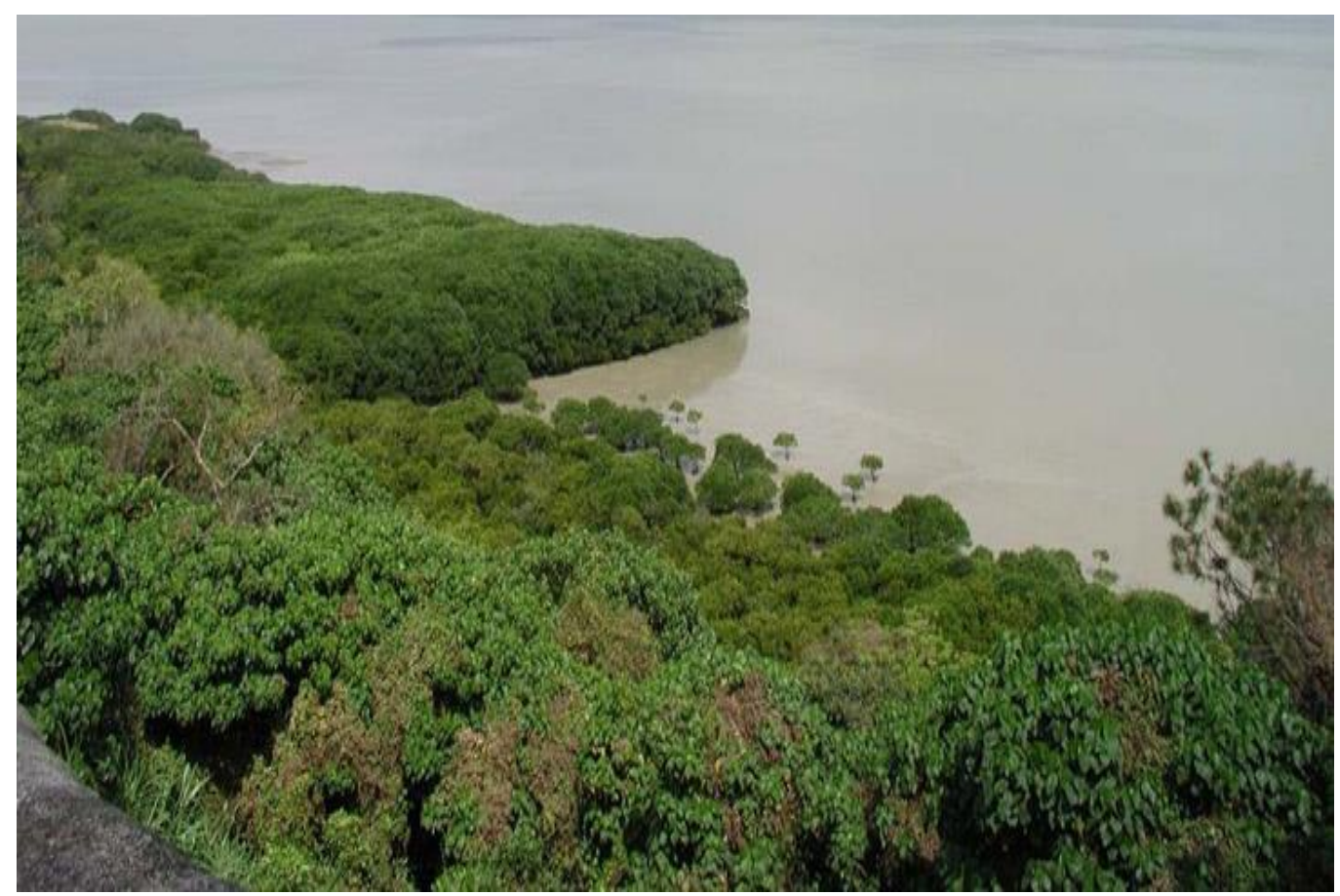

Figure 5: Karachi mangroves, Pakistan (Image courtesy of Rehan Ali via https://kashifiat.files.wordpress.com/2010/04/karachi_mangroves.jpg

Irrigated plantations are found in the plain areas of the country, mainly in Punjab and the Sindh. Major plant species include Dalbergia sissoo, Morus alba, Bombax cieba, Eucalyptus camaldulensis, A. nilotica, Melia azedarach, Populus spp., and Salix spp. Riverain forests are generally called the "Bela Forests" and found on the flood grasslands and the banks of the main rivers at Indus Basin. Plant species include Acacia nilotica, Tamarix dioica, Prosopis cineraria, D. sissoo, and Populus euphratica. Mangrow forests are located in the Indus delta swamps. The major plant species are Avicennia marina, Rhizophora tylosa and Ceriops tagal. Linear plantations along roads, canals and railway tracks include D. sissoo, A. nilotica, E. camaldulensis, Albizzia spp., Azadirachta indica, Tamarix aphylla, Populus spp., M. alba, Salix spp., and Melia azedarach. Farm forests are grown by the farmers and D. sissoo, A. nilotica, E. camaldulensis, Populus spp., Bombax cieba, and Melia azedarach are common plant species.

\section{Beekeeping practices: past, present, and future prospective}

Pakistan is obviously blessed with a wealth of naturally occurring flora and fauna which were started to be systematically recorded through the initiation of new projects. In 2007 the World Wide Fund for Nature (WWF) a non-governmental organization helped to published a field 
guide "Birds of Pakistan" and a National Insect Museum has been established which started to catalog the insects from old and new collections. With such a myriad range of climatic conditions and habitat types, it is not surprising that the country has a rich bee fauna that includes at least three species of native Apis honey bees. These are the dwarf honey bee A. florea, the hill honey bee A. cerana, and the rock honey bee A. dorsata. Also, A. andreniformes and $A$. laboriosa are almost certainly present and just awaiting discovery. Pakistan lies at the western end of the Asian honey bees range and the further dispersal of these bees is prohibited by the arid regions of Afghanistan. Interestingly, A. florea which is now found in Oman is most likely due to the introduction by humans rather than by natural spread. This natural arid barrier has prevented A. mellifera (which dispersed out of Africa) and the Asian honey bees from ever mixing. Therefore, over evolutionary time different pests and pathogens associated with each Asian honey bee species and A. mellifera have arisen separately. Currently there are an estimated 10,000 beekeepers in Pakistan managing almost 600,000 A. mellifera colonies producing more than 12,000 tons of honey annually. Beekeeping in Pakistan is mainly focused in KPK and central and north regions of Punjab but nowadays it is growing rapidly. A survey of beekeepers and honey hunters revealed that approximately 60 tons, 70 tons, and 10 tons of honey was harvested from A. cerana, A. dorsata and A. florea bee colonies per annum and the vast majority of that honey used for personal consumption or sold locally. Honey produced in Pakistan enjoys good repute in the Middle East due to its unique taste and quality. Pakistan exports around 4,000 tons of the honey with the worth of about $\$ 23.00$ million to Arab countries every year. 


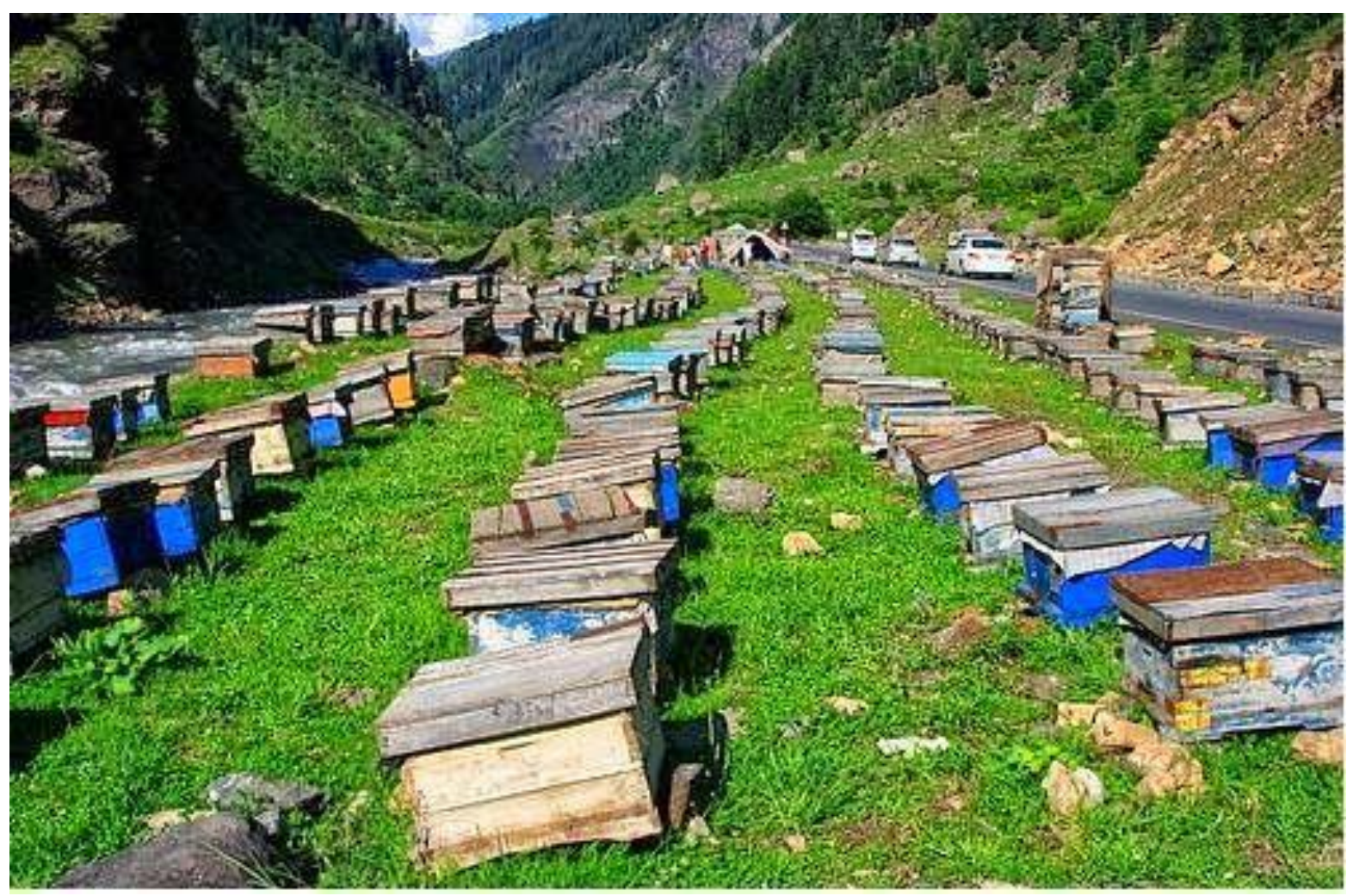

\section{Figure 6: A stunning view of honey bee farm in Pakistan (Image courtesy Ahsan Khalil via https://www.pinterest.com/pin/300544975105555141/)}

A. mellifera colonies were introduced to subcontinent by Sir Louis Dane during 1908, but these colonies soon died due to excessive rains and lack of expertise. During that time, a Punjab Beekeepers Association was founded by Mr. Brooks (Shimla High School) and Mr. Carson, Assistant Professor Entomology at Lyallpur (now Faisalabad). In 1910, A. mellifera colonies were shifted to Lahore (Pakistan) for rearing and acclimatization but no satisfactory results were obtained. In 1927, Jagjit Singh who was working at Faisalabad imported the honey bees from Italy but not succeeded. In 1930, Mian Afzal Hussain (Entomologist) started to rear A. mellifera first time in Murree. In 1934, A. mellifera colonies were brought to Entomology Department, Faisalabad Agriculture College that initiated their rearing first time in plain areas and started experiments. It was found at that time if an old queen bee would be replaced by a new one, then the bee colonies would become stronger and tolerant to hot summer. In 1940, A. mellifera colonies acclimatized in local environmental conditions that proved to be the start of a potential beekeeping industry in the country. Beekeeping started in Haripur (1940) and many research 
stations were established in Peshawar (1948), Chattar, Sialkot, Lahore, Rawalpindi, and Hassanabdal.

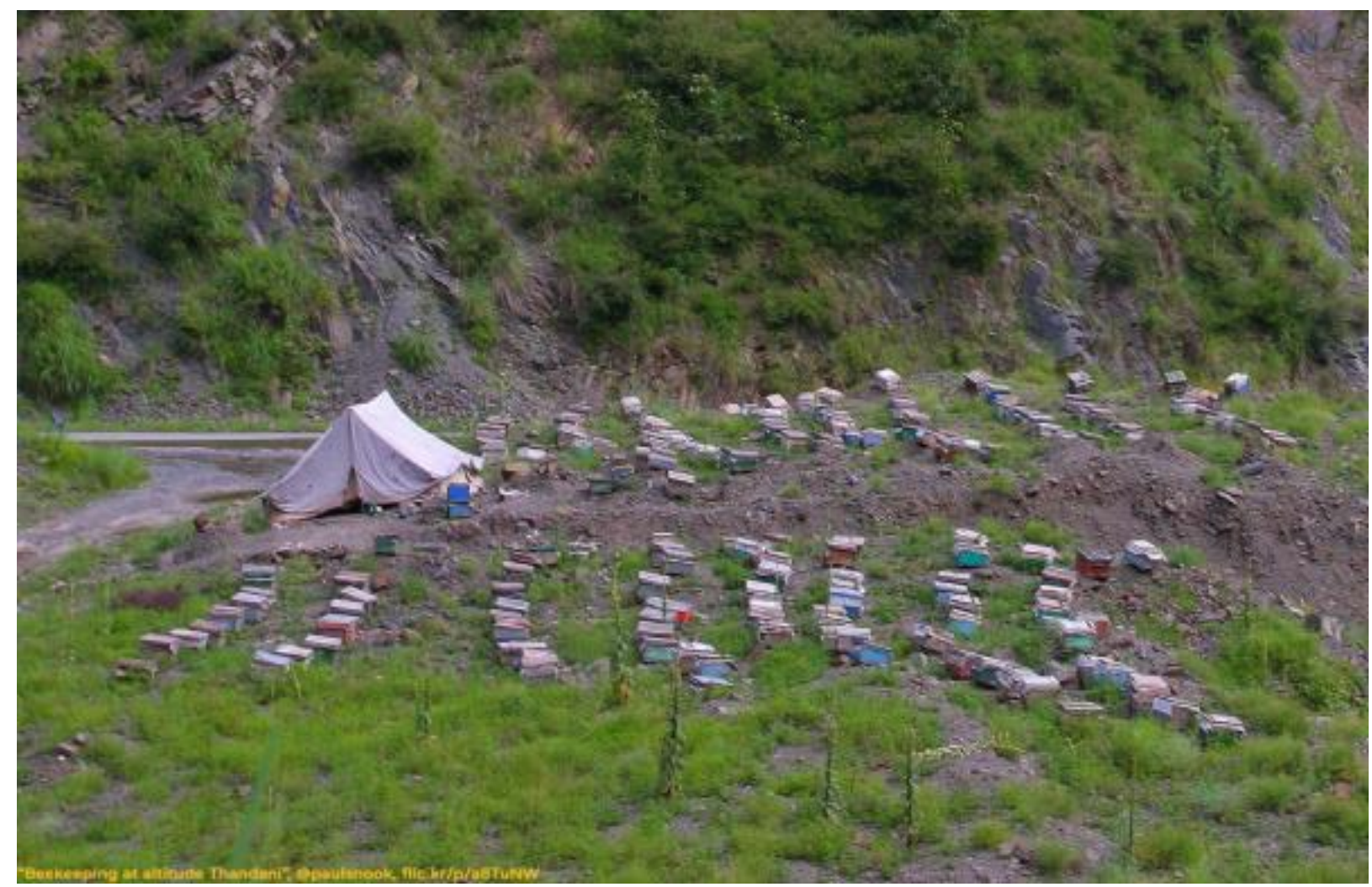

Figure7: Beekeeping at Thandani, Pakistan, (Image courtesy of Paul Snook via https://www.planbeeltd.com/tag/pakistan/)

The frontier beekeeper's association (1954) and All Pakistan beekeeper's association (1956) were established with their headquarters in Peshawar and Faisalabad respectively but they didn't operate well. During 1977-79, A. mellifera colonies imported from Australia (as packaged bees) were further acclimatized at the National Agriculture Research Centre (NARC), Islamabad. These colonies initially suffered through many colony losses and were changed by splitting and procuring additional colonies. In 1988-1992, Pakistan-German honey bee promotion program for training in honey bee colony management and modern mite control measures were introduced. Mite infestation was one of the problems that caused the failure of previous introductions of $A$. mellifera colonies. More recently the promotion of sustainable beekeeping and training in mite management is being carried out by Honeybee Research Institute (HBRI) of NARC, Agricultural Research Institute, Tarnab Peshawar, and Beekeeping Research Station, Rawalpindi. In past few years, the numbers of A. mellifera colonies have grown through 
practicing queen rearing and colony multiplication from 10 colonies to hundreds of colonies that had been distributed to beekeepers, government, and research institutes by HBRI. These colonies have now spread across a wide region of central Pakistan which is the most suitable for beekeeping. Prior to the large influx of $A$. mellifera colonies, beekeepers in the mountainous regions were maintaining $A$. cerana colonies as their main source of honey production, in addition to traditional honey hunters that were harvesting the wild $A$. dorsata colonies from trees and collecting A. florea honey. However, during 1980- 1983 almost all of the A. cerana colonies kept in modern and traditional hives were killed by an epidemic of what is believed to be tracheal mite, but other diseases cannot be ruled out. It is likely that the underlying cause was the transfer of diseases from A. mellifera to A. cerana since colonies of both species were kept in close proximity. A similar situation also occurred in India when the native A. cerana population was devastated by what is thought to be an epidemic of sacbrood contracted from imported A. mellifera colonies. Soon after the import of A. mellifera colonies, high yields of honey (40-50 kg per colony per annum) were recorded. But later, 1981 beekeepers started to report problems associated with the ectoparasite honey bee mite Tropilaelaps clareae. This mite has a similar life-history to the infamous Varroa mite in that it reproduces within the honey bees' sealed brood cells. It is about half the size of Varroa, has a long and thin body shape and its natural host is $A$. dorsata. However, there is less information about its biology and it appears to be unable to survive without the presence of brood since it is poorly adapted to a phoretic lifestyle. It is believed to have a second unknown non-honeybee host on which it survives during the period when $A$. dorsata is migrating. However, it has been able to successfully exploit A. mellifera as a new host where it is believed to have caused up to $50 \%$ of colony losses in India, and decimated colonies in Afghanistan, causing an estimated $95 \%$ of colony losses in just three years. Therefore, it is a serious pest and beekeepers need to control mite numbers by using acaricides or creating brood less periods. To add to their problems Varroa destructor was reported in 2002 and typically was already widely spread throughout their A. mellifera colonies. The presence of these two ectoparasitic mites is estimated to have reduced honey production by up to $50 \%$ as beekeepers learn how to manage them. Currently, beekeepers use flumethrin and fluvalinate strips imported from China and it is unclear if resistance has yet appeared. Formic acid is also used and trials using oxalic acid at National Apicultural Research Center (NARC) have confirmed that under local conditions it is effective and this will be phased in over the coming 
years. In addition to the mite problems, the other problems faced by beekeepers are those familiar to most beekeepers such as American Foulbrood (AFB), chalkbrood and pesticides used by farmers that have increased almost ten-fold during the last ten years.

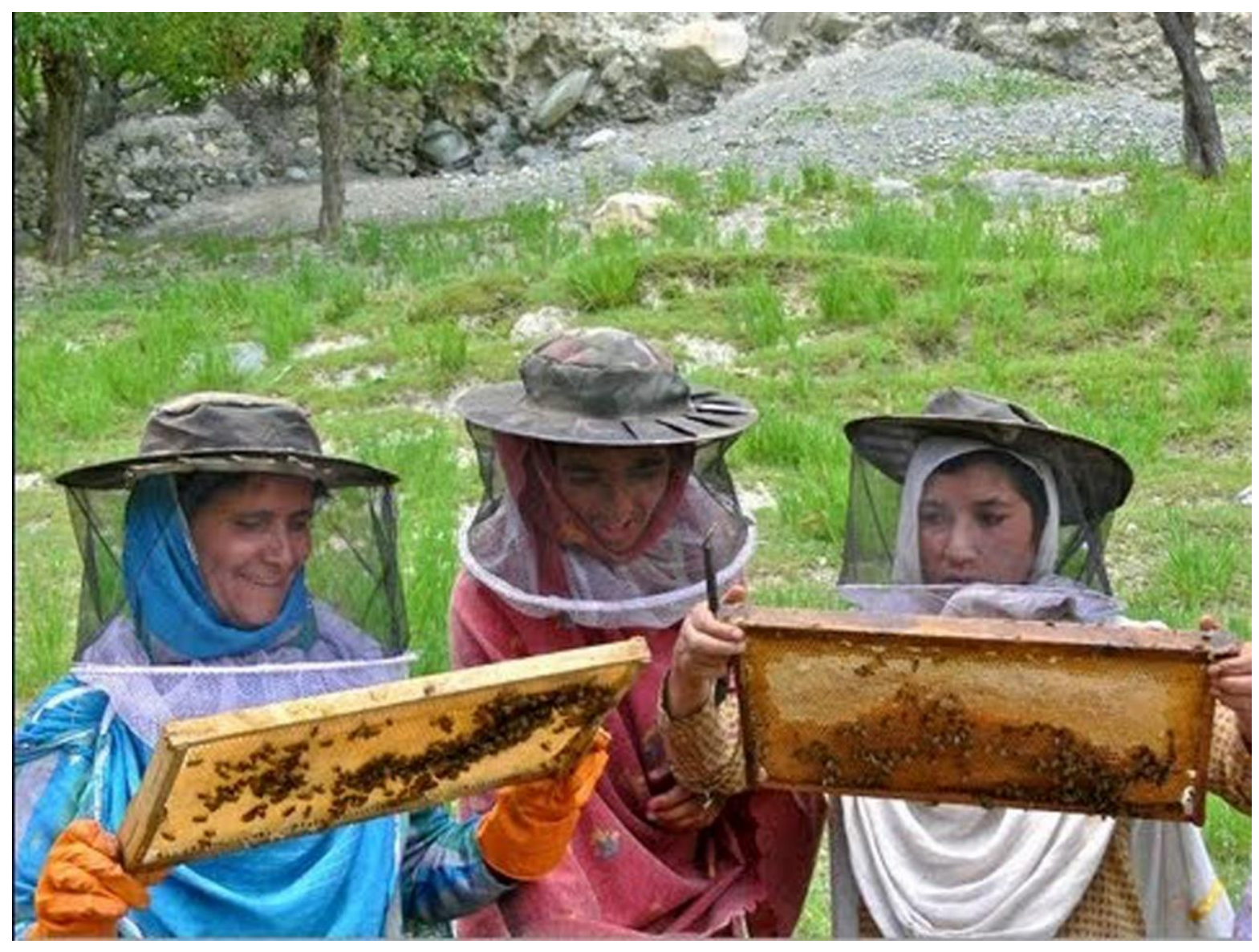

Figure 8: Women empowerment through honey bee farming: Image courtesy of Hashoo Foundation via http://i.ytimg.com/vi/KI4Pa2pfPZY/hqdefault.jpg

Despite these difficulties, the future of beekeeping in the country looks bright. Pakistan is producing high quality honey of different flora that includes citrus (Citrus spp.), acacia (Acacia spp.), clover (Melilotus officinalis), ziziphus (Ziziphus spp.), eucalyptus (Eucalyptus spp.), loquat (Eriobotrya japonica), shain, kalongi (Nigella sativa), mosquite (Prosopis juliflora), sheesham (Dalbergia sissoo), sunflower (Helianthus annuиs), rape and mustard (Brassica spp.), garranda/ currant bush (Carissa opaca), robinia (Robinia pseudoacacia), and many more in various ecological areas. The congenial climatic conditions along with plenty of bee flora offer tremendous opportunities for the growth and expansion of sustainable beekeeping in the country. Honey bee flora is present on vast areas of the country locating in all the provinces 
together with northern areas, federally administered tribal area (FATA), and Azad Jummu and Kashmir (AJK). By the development of beekeeping practices in the country, large numbers of people are receiving self-employment as commercial beekeepers and improving their livelihoods.
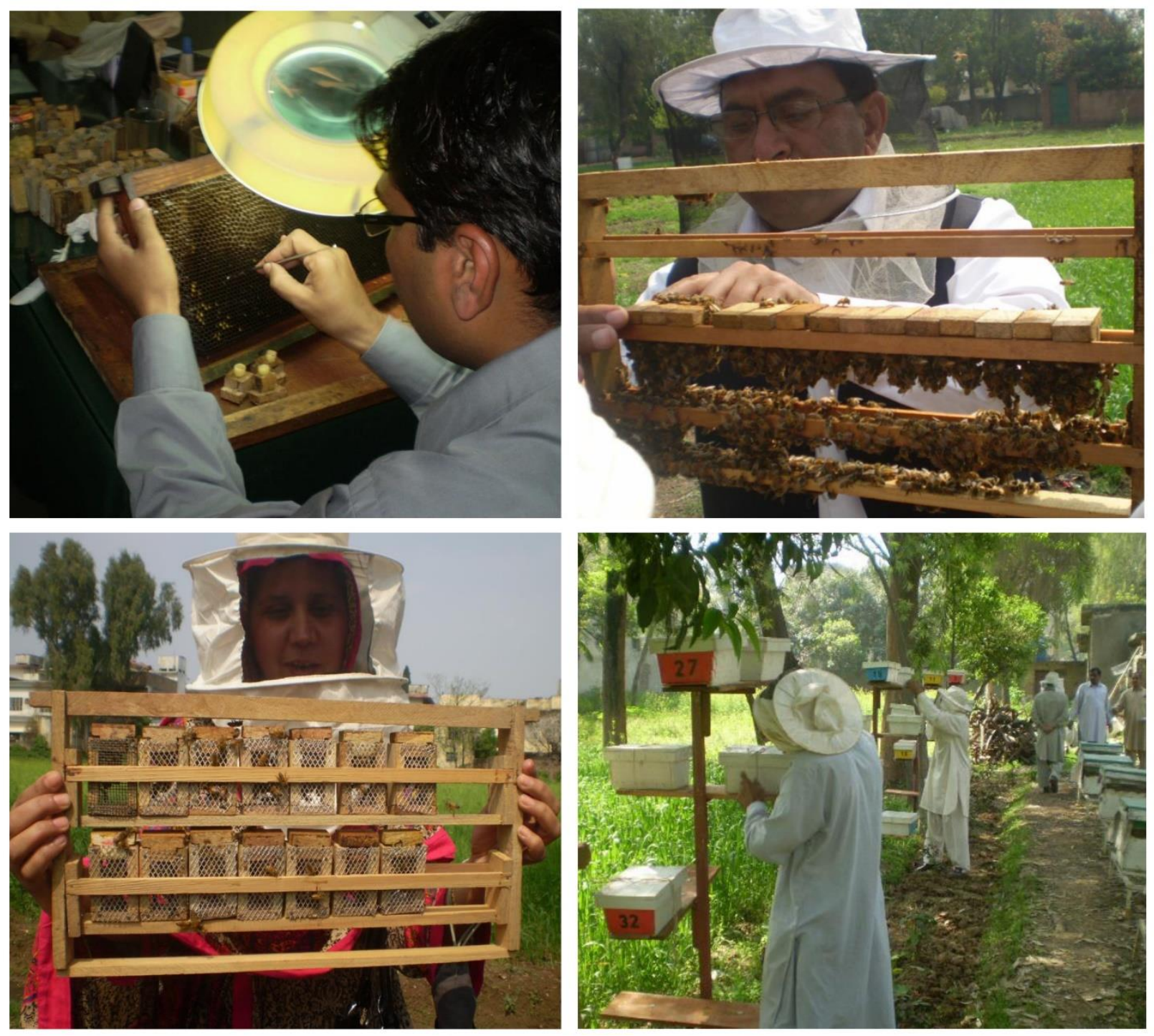

Figure 9: Honey bee queen rearing training course at Beekeeping Research Station, Rawalpindi, Pakistan.

The honey crop can be harvested with maximum yield from the areas where natural plantation and crop farming is common. Chakwal, Mianwali, Attock, Sargodha, Duska all located in Punjab province are considered the ideal locations for beekeeping; while in the Khyber Pakhtunkhwa province, Karak, Kohat, Swat, Bannu, and Chitral are most favorable places honey 
production. In the Balochistan province, Quetta, Ziarat valley, Naseerabad, and Kalat; and in Sindh province, some places like Thatta, Sujawal, Mirpur Khas, Hyderabad, and Gularchi area are best suited for honey bee farming. In addition, 160,000 hectares of mangrove forests in the coastal belt and the Koh Suleman range of south Punjab are another possible honey sources which are yet to be explored. Northern areas of Pakistan blessed with a plethora of natural plantations are the principal sources of nectar and pollen for A. cerana (the species restricted to hills and foothills of Pakistan). Currently, beekeeping industry is supporting almost 27,000 families, who are adopting commercial beekeeping as self-employment for their livelihoods. Ziziphus honey also is known as the jujube, is a dark non-granulating honey with a strong flavor and aroma. This type of honey is highly demanded locally and by the Arab export markets. In addition to the Ziziphus crop in the autumn, beekeepers take another 2-3 honey crops yearly. This can be from the flowers of oil-seed rape and citrus trees in the spring, followed by acacia and clover crops in the summer. Most of A. mellifera beekeeping is largely migratory, moving the bees from crop to crop. It proposes that the beekeepers can exploit the wide range of climate conditions and never need to sugar-feed their bees as forage is present year-round. Many research institutes (HBRI of NARC; ARI Tarnab, Peshawar; Beekeeping Research Station, Rawalpindi) and national universities (e.g. PMAS Arid Agriculture University Rawalpindi; Punjab University Lahore, etc.) are working on a different aspect of bee research in Pakistan. NARC has established a honey-testing and quality laboratory to promote the value of bee products. It will assist the beekeepers to develop their export market by addressing issues like potential antibiotic and pesticide residues. The research institutes are regularly organizing the beekeeping training courses for people to adopt beekeeping as a cottage industry. Many workshops are organized to provide the latest information and research findings in the field of Apiculture. Queen rearing programs have been established at research institutions where handson training is provided. In Punjab, apiculture is being offered for master students which is proving popular with the students. A. cerana beekeeping is again being encouraged in the mountainous regions where it is better adapted than A. mellifera and does not suffer from mite problems. Pakistan is a place where beekeeping has real potential to expand to exploit the wide range of climatic conditions and different flowing seasons the country has to offer. Beekeeping and honey production is becoming a profitable business in Pakistan and it deals with eco-friendly practices. The non-framing business activities related to apiculture have a wide perspective to 
deliver an extensive spectrum of economic contributions. Supplementary paybacks from beekeeping practices are associated with the biological nature of bee activities, like pollination services and conservation of natural flora.

\section{References}

Ahmad, R., Muzaffar, N. 1984. Jadeed Magas Baani (In urdu). Pakistan Agricultural Research Council, Islamabad, 1984, 12-23.

Khan, Khalid Ali, Ansari, Mohammed Javed, Al-Ghamdi, Ahmad . Sharma,Deepak, Ali, Hussain. 2014. Biodiversity and relative abundance of different honeybee species (Hymenoptera: Apidae) in Murree-Punjab, Pakistan. Journal of Entomology and Zoology Stidies. 2 (4): 324-327.

Khan, Muhammad Amir. 2015. Honey. Trade Development Authority of Pakistan Government of Pakistan Regional Office Peshawar. https://www.tdap.gov.pk/doc_reports/REPORT_ ON_HONEY.pdf

Lashari, Kamran. 2009. Land use atlas of Pakistan. Ministry of Environment Government of Pakistan. https://wedocs.unep.org/bitstream/handle/20.500.11822/9393/- Land_ Use_ Atlas_of Pakistan-2009Pakistan_LandUseAtlas_2009.pdf.pdf? sequence=3\&is Allowed=y

Mahmood, Rashid and Rafique Muhammad Khalid. 2018. Making Pakistan from Honey Importing to Honey Exporting Country by PARC. www.parc.gov.pk/index.php/en/ component/ content/article/168-parc-flash-news-2018/1598-making-pakistan-fromhoney-importing-to-honey-exporting.

Sheikh, Mahmood Iqbal. Original edition, 1993. Trees of Pakistan: Citeseer.

Sulemani, Shahid. 2018. Peshawar's honey market sweetens the lives of millions in the Arab world. http://www.arabnews.com/node/1365661/food-health

Waghchour-Camphor, Elizabeth and Martin, Stephen, 2008. Beekeeping in Pakistan: A bright future in a troubled land. American bee journal. 726-728. 
Khalid Ali Khan has a PhD in Entomology/Apiculture from King Saud University, Riyadh, Saudi Arabia. In 2010 he joined as a research scientist at Beekeeping Research Station, Rawalpindi, Pakistan. Dr. Khan has continued his interest in the field of Apiculture. He secured a position of an Assistant Professor in 2018 at King Khalid University, Abha, Saudi Arabia. He is involved in the experiments including structural and functional variability of gut microbial communities associated with honey bees, bee health, molecular aspects of bee

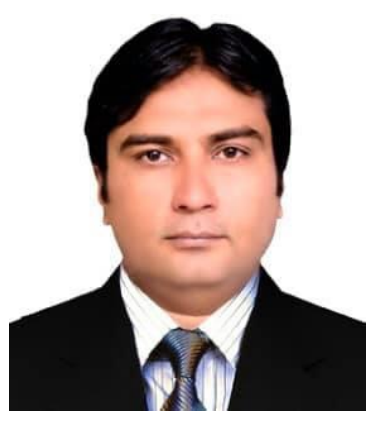
pathogens, and pollination ecology of Apis and non-Apis bees. His research interests also include the physico-chemical characterization of honey, propolis, and other bee product. He has published more than 70 research articles in international peer reviewed journals. 